\title{
Article
}

\section{Relationship between Physical Properties of Bread Dough Secondly Fermented in Several Conditions and its Baking Characteristics}

\author{
Shoichi IWASE ${ }^{* \dagger}$, Makoto MIURA ${ }^{* *}$, and Shoichi KOBAYASHI ${ }^{* *}$ \\ ${ }^{*}$ The United Graduate School of Agricultural Sciences, Iwate University, \\ 3-18-8, Ueda, Morioka, Iwate 020-8550, Japan \\ ${ }^{* *}$ Department of Agro-bioscience, Faculty of Agriculture, Iwate University, \\ 3-18-8, Ueda, Morioka, Iwate 020-8550, Japan
}

\begin{abstract}
Bread dough exhibits unique viscoelastic behavior, and the relationships between the properties of bread dough and the quality of final products have not been clear. The objectives of this study are to predict the baking characteristics using physical properties of bread dough. Several kinds of dough were prepared at three levels of second fermentation time $\left(35,50\right.$ and $65 \mathrm{~min}$ at $\left.38^{\circ} \mathrm{C}\right)$, which seriously affects baking characteristics. Breads were made from these kinds of bread dough. Specific gravity and $\mathrm{pH}$ of the dough decreased with increasing time of the second fermentation. The bread dough with $50 \mathrm{~min}$ of second fermentation time had the lowest value of mechanical loss tangent of $0.87 \pm 0.03$. Dielectric loss tangent of the dough increased with increasing second fermentation time. The non-liner multiple regression models using the values of physical properties of the dough as independent variables provided a good prediction of the loaf volume $\left(R^{2}=0.87 \sim 0.94\right)$.
\end{abstract}

Key Words: Bread dough / Physical properties / Baking characteristics / Non-liner multiple regression model

\section{2 次発酵条件を変化させたパン生地の物性と製パン特性との関連性}

$$
\text { 岩瀬 祥一 }{ }^{*} \text {, 三浦 靖**, 小林 昭一 }{ }^{* *}
$$

（原稿受理：2005年11月2日）

1. 緒言

日本で1年間に消費される食品用途の小麦は，2001年度に 約408万トンに達し, わが国は世界でも有数の消費国である. ${ }^{1)}$ 小麦を利用する場合に穀粒のままで食用することは少なく， そのほとんどが製粉された後に種々の食品に加工される. 例 えば, ベークド製品であるパンやクッキー, 麺類であるうど んや素麺などの加工食品があげられる. これらでは, 小麦粉 に水を加えてせん断を加えることにより生地を形成してい る. すなわち, 小麦粉に水を加えて混捏すると, 小麦タンパ ク質の主要成分であり分子量が約 5 万の球状タンパク質であ りその水和擬集体が著しく粘性を示すグリアジンと, 分子量 が約 50 万の䋊維状タンパク質でありその水和擬集体が高い弾 性を示すグルテニンとがグルテンと呼ばれる複合体を形成 して網目構造を呈し, 独特の粘弾性を発現する. パン生地の 力学特性は, 製造工程 (混捏, 発酵, 分割, 成形など) にお いて重要な制御因子であり, 最終製品の品質にも強く影響し ていることが経験的に知られている. そこで, パン生地の力

$*$ 岩手大学大学院連合農学研究科

厂 020-8550 岩手県盛岡市上田 3-18-8

** 岩手大学農学部農業生命科学科

T 020-8550 岩手県盛岡市上田 3-18-8

† E-mail:u7506002@iwate-u.ac.jp, Tel:+81 19-621-6148
学特性を測定する試験機として, パドルで生地を混捏したと きの抵抗の経時変化を測定するファリノグラフ ${ }^{2-4)}$, 混捏時の 攪拌子の回転軸に掛かるトルクを測定するミキソグラフ ${ }^{5-7)}$, 生地の伸展性を評価するエクステンシグラフ ${ }^{8,9)}$ などが従来 から用いられてきた。しかし，これらの試験機は，その測定 值が装置固有のものであるばかりでなく, パン生地の力学的 挙動を詳細に解析するためには十分な情報を与えず，パン生 地の工程管理に直接に測定值を用いるのには不十分であっ た. ${ }^{10)}$ 近年では，微小な正弦応力または正弦ひずみを種々の 周波数で試料に負荷し，ひずみまたは応力を測定する動的粘

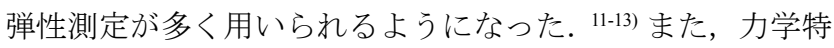
性を測定する以外にも生地の膨張力や二酸化炭素ガス発生 量を測定する方法などもある。. 14,15) さらに, 電磁気学的特性 である誘電率を計測することで，ガス発生量を測定したり ${ }^{16)}$, パン生地の水分含量などの配合条件とガラス転移温度の変 化との関連性 17) を検討するなど，誘電特性を食品の計測に利 用する動きがある. 18) しかし, 混捏や発酵の操作終点の判断 をいまだに目視で行うという伝統的あるいは職人的な技法 の占める割合が依然として大きい。 また，多くの試験機が開 発され，そして数多くの理化学的測定が行われているにもか かわらず，小麦粉生地が複雑な多成分の不均一混合系である ために，小麦粉製品の生地物性と製品特性との関連性は十分 
に解明されていない. 最近では, タンパク質-ラウリル硫酸ナ トリウム（SDS）沈降法により食パンのローフ体積を予測す ること ${ }^{19,20)}$ や，ミキソグラフを用いて食パンのローフ体積を 予測する手法 ${ }^{21,22)}$ が報告されている. ところが, SDS 沈降法 は測定時間が長く, しかも熟練が必要であるために誰しもが 一定の值を取得しにくい. また，パン生地のミキソグラムと ローフ体積との決定係数 $\left(R^{2}=0.51\right.$ または 0.65$)$ が低かったり, 決定係数が高い場合は重回帰分析に用いる変数の独立性に

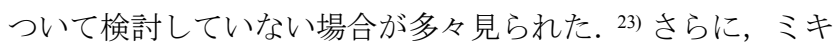
ソグラムでは生地混捏特性しか得られない。したがって, 食 パン製造の全工程中におけるパン生地の物性変化を測定で きる手法が求められている.

そこで, 本研究ではパンの理化学的性状を生地調製の段階 で制御することを目標として, パン生地の混捏や発酵の条件 がパン生地物性と製パン特性（ローフ体積, 比容積, 焼減率, 内相の硬さ, 気孔構造）に大きな影響を与えていることに着 目し，まず製パン工程中の2次発酵時間を 3 水準に設定してパ ン生地を意図的に作り分け，これらのパン生地物性と製パン 特性との関連性について検討した。

\section{2. 実験}

\section{1 試料}

食パンの原材料には, 一等強力小麦粉（「イーグル」, Lot. 020327AE6, 日本製粉(侏)), 食塩 (「塩」, 財塩事業センター), グラニュー糖 (「テーブルシュガー」, 日新製糖(侏) ), ショート ニング (「ナチュラル・ショートニング」, 月島食品工業(侏)， 脱脂粉乳（「ローヒート」，森永乳業(株)，ドライイースト (「saf-instant $\rfloor,$ S. I. Lesaffre社), イースト (「Cオリエンタルフー ド」, 組成: 塩化アンモニウム $20.0(\%, \mathrm{w} / \mathrm{w})$, 硫酸カルシウム 20.0 $(\%, \mathrm{w} / \mathrm{w})$, 炭酸カルシウム $10.0(\%, \mathrm{w} / \mathrm{w}), \mathrm{L}-$ シスチン $2.0(\%, \mathrm{w} / \mathrm{w})$, $\alpha$-アミラーゼ $1.0(\%, \mathrm{w} / \mathrm{w})$, プロテアーゼ $1.0(\%, \mathrm{w} / \mathrm{w}), \mathrm{L}-ア ス$ コルビン酸 $0.6(\%, \mathrm{w} / \mathrm{w})$, その他に小麦粉, トウモロコシデン プン, $\mathrm{NaCl}$, 麦芽粉末が $45(\%, \mathrm{w} / \mathrm{w})$, オリエンタル酵母工業 (株), 脱塩水を用いた. 試料の被覆剤にはn一へキサデカン（特 級, 和光純薬工業(株) , 比重測定での媒体にはn-へキサン (一 級, 和光純薬工業(侏) をそれぞれ用いた。

\section{2 食パン生地および食パンの調製}

Table Iに示したホワイトブレット配合で, Fig. 1に示したス トレート生地製法により2次発酵時間を $35,50,65$ 分間の3段 階に変化させて山型食パンを調製した. 寸なわち, 室温 $20^{\circ} \mathrm{C}$

Table I. Formula for white pan bread.

\begin{tabular}{lc}
\hline Ingredient & Flour basis $[\%, \mathrm{w} / \mathrm{w}]$ \\
\hline Wheat flour & 100.0 \\
Salt & 2.0 \\
Granulated sugar & 5.0 \\
Shortening & 5.0 \\
Non-fat dry milk & 2.0 \\
Dry yeast & 1.2 \\
Yeast food & 0.5 \\
Water & 66.0 \\
\hline
\end{tabular}

でミキサー（SKミキサーSK20C，エスケーミキサー侏）を使 用してショートニングを除く全材料を低速（100 rpm）で3分 間，中速 $(200 \mathrm{rpm})$ で2分間，高速 $(280 \mathrm{rpm})$ で3 分間混捏 した後にショートニングを添加し, 再び低速で 3 分間, 中速

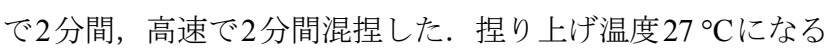
ように混捏したパン生地をユニットオーブン（UFK-8-1-2-2, 共立プラント工業(株) の発酵器部にて庫内温度 $27^{\circ} \mathrm{C}$, 庫内湿 度 $75 \%$ RHで90分間（60分間後にパンチを実施）だけ1次発酵 させた。ここで，パンチとは 1 次発酵工程において発酵器か らパン生地を取り出し, 三つ折に畳んでから再び発酵器に戻 す操作をいい，大きな気泡を除去および細分化することなら びにパン生地中に空気を供給してパン生地の中心部と表層 部の発酵状態を均等化することを目的にしている．続いて, パン生地をケッパーで $310 \mathrm{~g}$ に分割し, $27^{\circ} \mathrm{C}, 75 \% \mathrm{RH}$ で 15 分 間だけ生地を静置した（ベンチタイムと呼ばれている）。そ して，U字型ステンレスパイプ（直径 $8 \mathrm{~mm}$ ) の間にパン生地 を置き, 生地の厚さが $8 \mathrm{~mm}$ になるよう麺棒で板状に伸ばして から手作業で丸めて成形した。成形したパン生地をワンロー フ型パン焼成型（アルタイト食パン型，上面：W $187 \mathrm{~mm} \times$ D $95 \mathrm{~mm}$, 底面:W $182 \mathrm{~mm} \times \mathrm{D} 90 \mathrm{~mm}, \mathrm{H} 90 \mathrm{~mm}$ ) に入れ, ユニッ トオーブンの発酵器部を使用し， $38^{\circ} \mathrm{C}, 85 \% \mathrm{RH}$ で 35 分間, 50 分間および 65 分間という 3 水準で 2 次発酵を行った. 最後 に，ユニットオーブンの焼成器部を用いて上火設定 $180^{\circ} \mathrm{C}$, 下火設定 $260^{\circ} \mathrm{C} て ゙ 25$ 分間だけ焼成した.

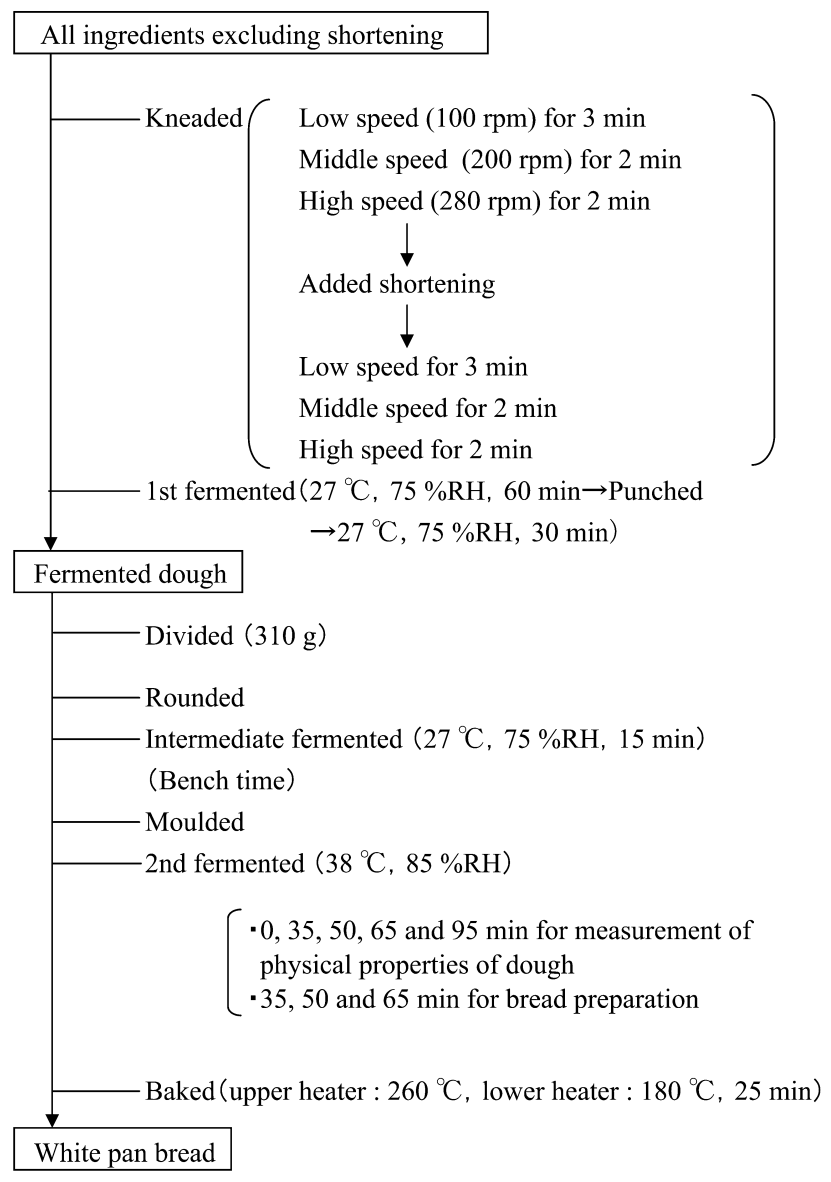

Fig. 1. Preparation procedure of white pan bread. 


\section{3 パン生地の物性測定}

\section{(1) 比重}

パン生地の物性変化を詳細に把握するため, 上記の2次発 酵時間の 3 水準に加えて 0,95 分間を追加した 5 水準で調製し たパン生地について比重を測定した。固体比重測定装置 (XS105DU，メトラー・トレド(侏) を用いてアルキメデス法

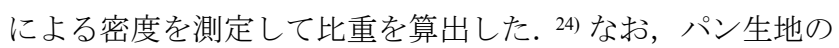
一部をハサミで切り取って試料を採取したが, 試料中への n一へキサン浸入を防ぐために試料断面に露出した気泡を指で つまんで接合させて閉じた. また, $300 \mathrm{ml}$ 容積のガラス製ビー カーに試料の上面より $10 \mathrm{~mm}$ 以上液面が高くなるように $20^{\circ} \mathrm{C}$ のn-ヘキサン（密度 $0.6667 \mathrm{~g} \cdot \mathrm{cm}^{-3}$ ) を満たした.

\section{(2) $\mathrm{pH}$}

食品用 $\mathrm{pH}$ 電極（6252-10D，(株堀場製作所）を装着した $\mathrm{pH}$ 測定装置（F-23，(株堀場製作所）を用いて焼成型に入れたま まで生地のpHを測定した。

\section{(3) 動的粘弾性}

定格トルク容量 $1.96 \times 10^{-2} \mathrm{~N} \cdot \mathrm{m}$ で, 定格荷重容量 $19.6 \mathrm{~N}$ の荷 重変換器を装着した動的粘弾性測定・解析装置（MR-500, (株ユニービーエム) を用いてパン生地の動的粘弾性を測定した. 平行平板（上部板 : $\phi 20 \mathrm{~mm}$, 下部板 : $\phi 40 \mathrm{~mm}$ ) に隙間が発 生しないように $1.0 \mathrm{~mm}$ の間隔でパン生地を挟み込んだ. ${ }^{25,26)}$ なお， せん断速度は平行平板の間隔が広いと減少し，使用し た動的粘弾性測定・解析装置ではトルク出力がフルスケール の $0.2 \%$ 未満であると動的粘弾性測定の信頼性が失われるた

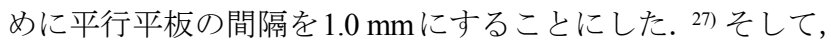
試料からの水分揮散を防止するために, 試料側面の露出部分 をn-へキサデカンで覆った. さらに, パン生地を測定治具に 装着する際に負荷されたひずみを緩和するために $38^{\circ} \mathrm{C} て ゙ 5$ 分 間静置してから動的粘弾性の周波数依存性試験を行った.

\section{i) 応力一ひずみの線形範囲}

それぞれのパン生地の応力ーひずみの線形範囲を測定し, 周波数依存性試験で試料に負荷する一定ひずみを決定した. すなわち, 試料温度が $38^{\circ} \mathrm{C}$, ひずみが $1.7 \times 10^{-5} \sim 1.7 \times 10^{-4}$ （振 動角範囲 0.01 0.1 deg), 周波数が $1 \mathrm{~Hz}$ で動的粘弾性のひずみ 依存性試験を行い, 貯蔵弾性率 $\left(G^{\prime}\right)[\mathrm{Pa} 〕$ から線形範囲を判 断した.

\section{ii) 動的粘弾性の周波数依存性}

パン生地の高分子物体としての粘弾性挙動を特徵づける ため, 上記i) で求めた弾性限界ひずみから定めた一定ひずみ を負荷し, 試料温度 $38^{\circ} \mathrm{C}$, 周波数 $10^{-2} \sim 10 \mathrm{~Hz}$ で $G^{\prime}[\mathrm{Pa}]$, 損失 弾性率 $\left(G^{\prime \prime}\right)$ [Pa]および力学的損失正接 $\left(\tan \delta_{\mathrm{G}}=G^{\prime \prime} / G^{\prime}\right)$ 〔 $]$ を測定した。

\section{(4) 誘電緩和}

誘電率分析装置（DEA2970, TA Instruments社）を用いてパ ン生地の誘電緩和測定を行った。測定センサにはセラミック 製平行板（W $25 \mathrm{~mm} \times \mathrm{D} 25 \mathrm{~mm} \times \mathrm{H} 1.5 \mathrm{~mm}$ ）を用い, 前述した 方法と同様にして試料を採取して測定センサに装着し, 平行 板間隔を $1.0 \mathrm{~mm}$ に設定した.ここで, パン生地は流動性があ る複雑な多成分不均一混合系であるため, 平行板との密着性 が低いと正確な值を得ることができない. このため, 平行板
間隔を $1.0 \mathrm{~mm}$ に設定した。試料温度 $38^{\circ} \mathrm{C}$, 周波数 $10 \sim 10^{3} \mathrm{~Hz}$

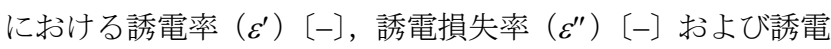
損失正接 $\left(\tan \delta_{\varepsilon}=\varepsilon^{\prime \prime} / \varepsilon^{\prime}\right)$ 〔一〕を測定した.

\section{4 パン生地の不凍水含量の測定}

グルテンの水和状態の変化は, パン生地の流動化を起こす 主な要因の一つである。よって，パン生地中の不凍水含量か らグルテンの水和状態の変化を捉え, それがパン生地の粘弾 性に及ぼす影響を検討した。すなわち，パン生地をアルミニ ウム製簡易密封型試料容器 $(10 \mu 1$, 容器 : 900793.901, 蓋 : 900794.901，TA Instruments社）に採取して密封した. 空のア ルミニウム製簡易密封型試料容器を対照とし, 示差走査熱量 計（2920型MDSCセルベース，TA-5200型熱分析システム, TA Instruments社）を用いて, $30^{\circ} \mathrm{C}$ で5分間保持して試料の初期 温度を平衡化してから $-55^{\circ} \mathrm{C}$ まで温度勾配 $5^{\circ} \mathrm{C} \cdot \mathrm{min}^{-1}$ で泠却 し, その温度で 5 分間保持してから $30^{\circ} \mathrm{C}$ まで温度勾配 $5^{\circ} \mathrm{C} \cdot \mathrm{min}^{-1}$ で加熱するプログラムでDSC曲線を取得した。凍結水量は, 示差走査熱量測定により水の融解に伴うエンタルピー変化 から測定できるが，不凍水含量はDSCでは測定できない. そ こで, 全含水量と凍結水量との差から間接的に不凍水量を測 定し, 次式(1)および(2)により不凍水含量 $[\%, w / w]$ を算出 した。

$$
\begin{aligned}
& W_{\mathrm{ufw}}=W_{\mathrm{tw}}-\Delta H_{\mathrm{f}} \cdot W_{\mathrm{s}} / L_{\mathrm{f}} \\
& \left(W_{\mathrm{ufw}} / W_{\mathrm{tw}}\right) \times 100
\end{aligned}
$$

ここで, $W_{\mathrm{ufw}}$ は不凍水量 $[\mathrm{kg}], W_{\mathrm{tw}}$ は試料の全含水量 $[\mathrm{kg}]$, $W_{\mathrm{s}}$ は試料の質量 $[\mathrm{kg}], \Delta H_{\mathrm{f}}$ は試料の融解潜熱 $\left[\mathrm{KJ}^{\mathrm{N}} \cdot \mathrm{kg}^{-1}\right], L_{\mathrm{f}}$ は実測した水の融解潜熱 $330\left[\mathrm{KJ} \cdot \mathrm{kg}^{-1}\right]$ である。なお， $W_{\mathrm{tw}}$ は $\mathrm{AACC}$ 標準法 44-15A $\mathrm{A}^{28)}$ に準じた常圧加熱乾燥法 $\left(103{ }^{\circ} \mathrm{C}\right.$, 30 h）で恒量になるまで試料を乾燥して求めた.

\section{5 パン生地のマルトース含量}

小麦粉中に含まれるマルトース量は痕跡程度にすぎない が，小麦粉に水を添加すると，損傷デンプンに $\beta$-アミラーゼ が作用して非還元末端からグルコース 2 分子単位で加水分解 されるために急速に増加する，これらのマルトースは，製パ ンにおける 2 次発酵後期に始まるマルトース発酵において不 可欠な基質である. ${ }^{29)}$ マルトース発酵の際には, このマルトー ス発酵による二酸化炭素ガス発生量の増加，パン酵母 (Saccharomyces cerevisiane) や乳酸菌が産生する有機酸の増加 によるパン生地の比重の低下，グルテン網目構造の構造緩和 による抗張力の低下と伸展性の増加などが考えられる. そこ で，2次発酵におけるパン生地中のマルトース含量を測定し， マルトース発酵とパン生地の粘弾性との関連性を明確にす ることを試みた，すなわち，2次発酵を5水準に変えて調製し たパン生地について, フェノールー硫酸法30)でパン生地中の マルトース含量を定量した。

\section{6 製パン特性}

\section{(1) ローフ体積}

2 次発酵時間を 3 水準に変えて調製した山型食パンについ て, AACC標準法72-10 $0^{31)}$ に準じ, ナタネ(農林16号, カネコ 
種苗(株) とポリメチルアクリレート樹脂製水槽（W $200 \mathrm{~mm} \times$ D $200 \mathrm{~mm} \times \mathrm{H} 200 \mathrm{~mm}$ ) を用いたナタネ置換法でローフ体積 (パ ン体積）を測定した。

\section{(2) 比容積}

ローフ体積 [ $\left.\mathrm{m}^{3}\right]$ をパン質量で除して比容積 $\left[\mathrm{m}^{3} \cdot \mathrm{kg}^{-1}\right]$ を求 めた. なお, 山型食パンではこの数值が品質にとって重要で あり，一般的に普通約 $5.0 \times 10^{-3} \mathrm{~m}^{3} \cdot \mathrm{kg}^{-1}$ 以上を示寸必要があると 言われている. ${ }^{32)}$

\section{(3) 焼減率}

焼減率は次式(3)で定義されるパンの焼成中に蒸発する水 分量とパン生地の質量比のことであり, 一般的に $10 \%$ 前後で あるとよいとされている. ${ }^{32}$

焼減率 $[\%, \mathrm{w} / \mathrm{w}]=\frac{\text { パン生地質量 }[\mathrm{kg}] \text { ーパン質量 }[\mathrm{kg}]}{\text { パン生地質量 }[\mathrm{kg}]} \times 100$

なお, パン生地質量は $310 \mathrm{~g}$ であり, パン焼成後に室温で30分 間だけ静置して粗熱を除去した後にパン質量を測定した.

\section{(4) 内相の硬さ}

最大力 $19.6 \mathrm{~N}$ のロードセルおよび円柱状プランジャー （No.3， ф16 mm×H 25 mm）を装着した単軸圧縮・引張型レオ メータ（RE-33005，(株山電）を用いて内相の硬さを測定した. すなわち, 山型食パンをパンスライサー (1枚切りスライサー FK21型, 冨士島工機株)）を用いて, ローフ両端部を厚さ $20 \mathrm{~mm}$ ずつ取り除いた. そして, 一方の末端から他方の末端 に向かって厚さ $10 \mathrm{~mm}$ と厚さ $25 \mathrm{~mm}$ に交互に切断し, 厚さ $25 \mathrm{~mm}$ の3枚のスライスを実験に供した. 試料の切断面の内相部分 を外皮層が入らないように 9 領域 $(3$ 列 $\times 3$ 段) に分割し, 上段 の左側から T1（Tはtopを意味する）, T2およびT3, 中段の左 側から M1（Mはmiddleを意味する）, M2およびM3，下段の 左側からB1 (Bはbottomを意味する), B2およびB3 と命名した. 予備検討の結果, これらの領域の硬さに試料の違いによる 明確な差異が見られた 1 1, M2およびB3の3領域を対象とした. 試料温度 $20^{\circ} \mathrm{C}$, 距離分解能 $0.01 \mathrm{~mm}$, 圧縮速度 $1.0 \mathrm{~mm} \cdot \mathrm{s}^{-1}$, 試 料の厚さの $80 \%$ を変形上限として単軸圧縮を行い, ひずみ 0.25 のときの応力を硬さ33) と定義した。

\section{(5) 内相の気孔構造}

厚さ $10 \mathrm{~mm}$ の 3 枚のスライスを試料にして $11, \mathrm{M} 2$ および B3の3 領域を対象とし, パーソナル画像処理・解析システム (DA-5000S, 王子計測機器(株) を用いて内相の気孔構造をディ ジタル画像解析した. まず, 原画像に対して濃度值の範囲を 0 255の 256 (8 bit) 階調に拡大寸る濃度階調変換を行った後, $3 \times 3$ マトリックスの4近傍についての強調フィルタ処理を施し て画像を鮮鋭化した. そして, 多重二值化イメージング法 ${ }^{34)}$ で前処理画像を 2 值化した. 寸なわち, 前処理画像の濃度值 ヒストグラムのピークに相当する濃度值をしきい值 5 とす る.この濃度值ピークの画素数の $10 \%$ に当たる画素数を有す る濃度值領域のうち濃度值の小さい方の境界の濃度值をし きい值 1 , 大きい方の境界の濃度值をしきい值 9 とした. さら に, ピーク濃度值から最も低い濃度值および高い濃度值の両
側の範囲をそれぞれ4等分してさらに6個のしきい值（しきい 值2，3，4，6，7，8）を設定した．各しきい值で2值化した 図形から外枠に接している気孔図形を除去した図形の論理 和を求め，気孔構造を表す図形を得た。そして，画像解析・ 計測ソフト (Image-Pro Plus Ver. 5.0, (株日本ローパー) を用い, 気孔面積率 $[\%]$, 気孔数 $[-], X$ 軸フェレ径 $[\mathrm{mm}], \mathrm{Y}$ 軸フェ レ径 $[\mathrm{mm}]$ ，楕円率〔ー〕を測定した。

\section{7 統計処理 · 解析}

2次発酵時間の長短が，パン生地の物性および製パン特性 に与える影響を明確にするためにTukey ${ }^{35)}$ の多重比較法 (SPSS 12.0.2J for Windows，エス・ピー・エス・エス株）で有意水準 $5 \%$ における検定を行った。 また，パン生地の物性と製パン 特性との関連性を検討するために重回帰分析を行った。

\section{3. 結果および考察}

\section{1 パン生地の物性}

\section{(1) 比重}

パン生地の比重は, 2次発酵95分間のパン生地を除いて2次 発酵時間が長くなるにつれてパン酵母が形成する二酸化炭 素ガス気泡の体積分率が増加することを反映して減少した (Table II ). 一方，2次発酵95分後のパン生地では，気泡の保 持性が著しく低下し，試料を採取する段階で破泡してしまっ たと考えられる.

\section{(2) $\mathrm{pH}$}

混捏直後に $\mathrm{pH} 5.80$ であったパン生地は, 1 次発酵, 分割, 丸め, ベンチタイム，成形という工程を経て 2 次発酵を開始 する際にはpH 5.31 に低下し, さらに2次発酵時間の経過にし たがって95分間後にはpH 4.80にまで低下した（Table III）。発 酵の進行に伴うパン生地の $\mathrm{pH}$ 低下は, 小麦粉や製パン用酵母 に存在する有機酸産生菌 (主に乳酸菌) による有機酸の産生, イーストフードに配合されているアンモニウム塩からの有

Table II. Specific gravities [-] of several kinds of bread dough prepared with different 2 nd fermentation time.

\begin{tabular}{ccccc}
\hline \multicolumn{5}{c}{ 2nd fermentation time [min] * } \\
\hline 0 & 35 & 50 & 65 & 95 \\
\hline $0.70 \pm 0.01^{\mathrm{a}}$ & $0.49 \pm 0.01^{\mathrm{b}}$ & $0.45 \pm 0.01^{\mathrm{c}}$ & $0.42 \pm 0.00^{\mathrm{d}}$ & $0.42 \pm 0.01^{\mathrm{d}}$ \\
\hline
\end{tabular}

Mean \pm standard deviation $(\mathrm{n}=3)$

*Values in the row followed by the same letter are not significantly different $(p<0.05)$.

Table III. pH of several kinds of bread dough prepared with different 2nd fermentation time.

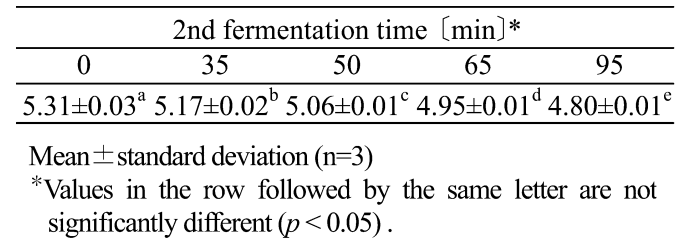


機酸の生成 $\left(\mathrm{NH}_{4} \mathrm{Cl}\right.$ から $\mathrm{HCl}$ が生成), パン酵母が産生する 二酸化炭素が水に溶解することによる炭酸の生成に起因す

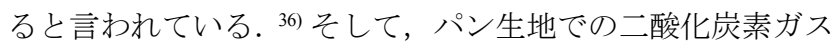
気泡の保持性は，パン生地 $\mathrm{pH}$ が 5.0 を下回ると急激に低下す

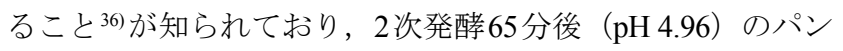
生地では比重測定後に, 数分間で破泡してしまった. した がって，本実験における2次発酵50分間までは，発生した二 酸化炭素ガス気泡がパン生地中に有効に保持されているが, それ以降は $\mathrm{pH}$ 低下ならびにパン酵母が産生するエタノール によりパン生地の網目構造の連続相を形成しているグルテ ンの水和性や高次構造が変化するために連続相の弾性が低 下し, 相対的に粘性が増加して二酸化炭素ガス気泡の保持性 が低下したと考えられる。

\section{(3) パン生地の動的粘弾性}

パン生地における応力ーひずみ線形範囲の上限ひずみは, それぞれ 2 次発酵開始時のパン生地で $5.1 \times 10^{-5}, 35$ 分間のパン 生地で $5.6 \times 10^{-5}, 50$ 分間のパン生地で $7.9 \times 10^{-5}, 65$ 分間のパン 生地で $4.7 \times 10^{-5}$, 95 分間のパン生地で $4.9 \times 10^{-5}$ であった. 動的 粘弾性の周波数依存性試験を行う際に試料に負荷する一定 ひずみには, 試料の個体差により弾性限界が多少は変動した としても, 動的粘弾性測定が応力ーひずみの線形範囲を冕脱 しないようにするため, 本実験ではそれぞれの弾性限界 $80 \%$

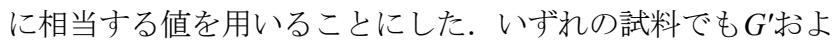
び $G^{\prime \prime}$ は, 測定周波数が低周波から高周波になるのにしたがっ て増加し, $\tan \delta_{\mathrm{G}}$ の值は逆に減少した (Fig. 2). 特に, 各試料 の $\tan \delta_{\mathrm{G}}$ に明確な差異が見られたのは, 本実験における低周波 領域にある $10^{-2} \mathrm{~Hz}$ においてであった. すなわち, $\tan \delta_{\mathrm{G}}$ の值 は, 2 次発酵開始時のパン生地で $1.12 \pm 0.04,2$ 次発酵 35 分後の パン生地で $1.37 \pm 0.04,2$ 次発酵 50 分後のパン生地で $0.87 \pm 0.03$, 2 次発酵 65 分後のパン生地で $1.17 \pm 0.04,2$ 次発酵 95 分後のパン 生地で $1.04 \pm 0.06$ であり, 2 次発酵 50 分後のパン生地で最低で あった。

Ferryによれば，角周波数 $10^{-5} \sim 10 \mathrm{rad} \cdot \mathrm{s}^{-1}$ の範囲における $G^{\prime}$, $G^{\prime \prime}, \tan \delta_{\mathrm{G}}$ の変化パターンから高分子は7 種類に大別できると 述べている. ${ }^{37,38)}$ 本研究での動的粘弾性測定の周波数範囲は, $10^{-2} \sim 10 \mathrm{~Hz}$ （角周波数 $10^{-3.6} \sim 10^{-1.8} \mathrm{rad} \cdot \mathrm{s}^{-1}$ ) というようにFerryが 議論している周波数領域の一部にしかすぎないために断言 できないが，非晶性鎖状高分子に似た動的粘弾性挙動を呈し た. 2 次発酵時間が異なるパン生地の $\tan \delta_{\mathrm{G}}$ の值に差異が見ら れたのは, 主にグルテン網目構造の変化に起因すると考えら れる. すなわち, 成形直後のパン生地では, 加工硬化のため に内部ひずみが最大となり, パン生地は強く引き締められた 状態にあると考えられる. しかし, 発酵時間が長くなるにし たがってこの内部ひずみは徐々に緩和され, しかも成形操作 によってパン生地同士が接合した部分ではタンパク質分子 内および/または分子閒の水素結合, 静電結合, ジスルフィド （SS）結合ならびに疎水性相互作用などによって架橋領域が 増加して粘弾性に富むグルテン網目構造が形成される。した がって, パン生地の抗張力が適度に低下して伸展性の良好 なパン生地に変化していくと考えられている. ${ }^{39)}$ 一方, 2 次 発酵時間 35 分間にしたパン生地では, 発酵時間が短いために 小麦粉中に存在する $\beta$-アミラーゼによる損傷デンプン粒の 加水分解が進行しつつも生地に加えられたひずみが十分に 緩和せず，しかも架橋領域が少ないために抗張力が低いと考
えられる。したがって，粘性に比べて弾性の寄与割合が低い ために $\tan \delta_{\mathrm{G}}$ の值が高くなったと思われる. 一方, 2 次発酵 50 分後のパン生地では, 発酵時間が長くなることで内部ひず みの緩和が十分に進行し, しかも架橋領域が増加するため, 粘性に比べて弾性の寄与割合が高くなって $\tan \delta_{\mathrm{G}}$ の值が低く なったと考えられる. そして，2次発酵時間を 65 分間および 95分間にしたパン生地では，パン酵母や乳酸菌などが産生す る二酸化炭素や有機酸によるパン生地の $\mathrm{pH}$ 低下, タンパク質 分子内/分子間のSH-SS 交換反応40) などが過度に進行してし まうために弾性に比べて粘性の寄与割合が高くなって $\tan \delta_{\mathrm{G}}$ の值が再び増加したと考えられる.

\section{(4) 誘電緩和}

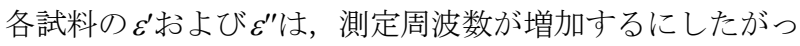
て低下したが， $\tan \delta_{\varepsilon}$ は逆に上昇した (Fig. 3). $\tan \delta_{\varepsilon}$ は本実験 での高周波領域にある周波数 $10^{3} \mathrm{~Hz}$ で試料間に明確な差異が 見られ，2次発酵開始時のパン生地で $3.83 \pm 0.02 ， 2$ 次発酵 35 分 後のパン生地で $6.14 \pm 0.01,2$ 次発酵 50 分後のパン生地で $7.39 \pm 0.20,2$ 次発酵 65 分後のパン生地で $8.48 \pm 0.60,2$ 次発酵 95分後のパン生地で $12.56 \pm 0.89$ というように2次発酵時間の延 長に伴って増加した.
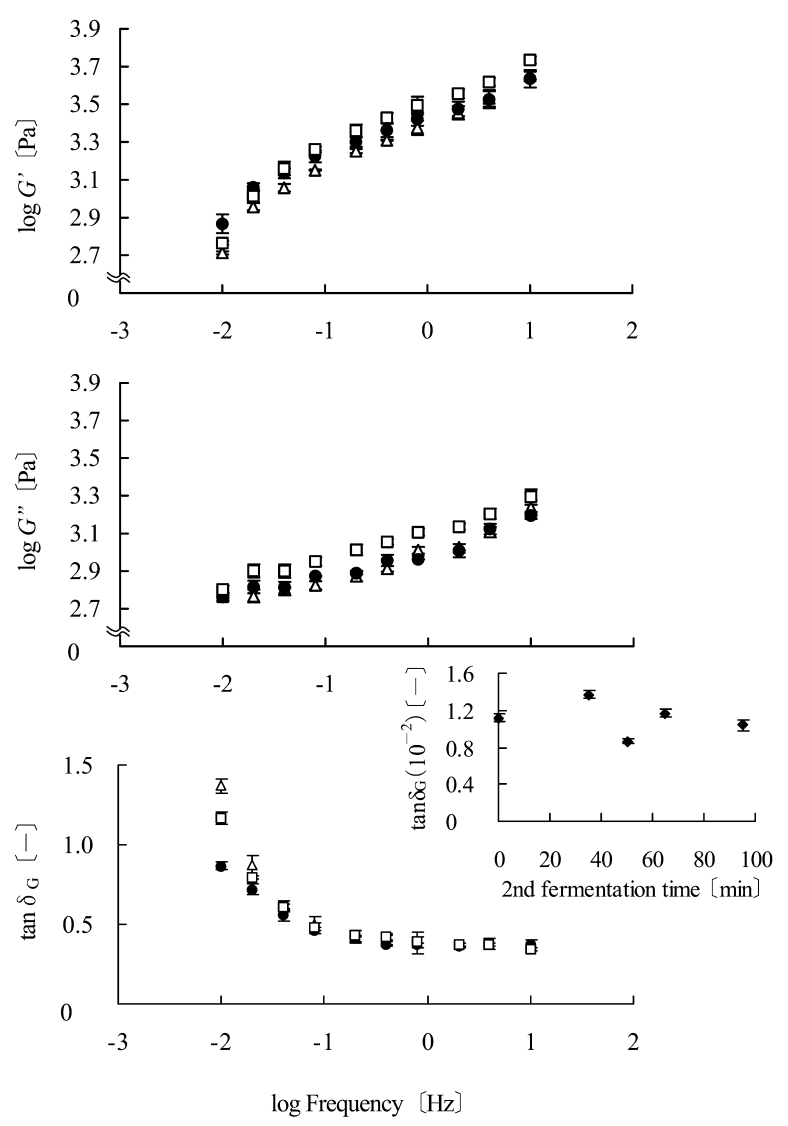

Fig. 2. Frequency dependence of dynamic moduli $\left(G^{\prime}\right.$ and $\left.G^{\prime \prime}\right)$ and mechanical loss tangent $\left(\tan \delta_{\mathrm{G}}\right.$ ) of several kinds of bread dough prepared with different 2 nd fermentation time.

Values are average \pm standard deviation of three replicates.

-, fermented for $50 \mathrm{~min}$; $\triangle$, fermented for $35 \mathrm{~min}$; $\square$, fermented for $65 \mathrm{~min}$.

The inset shows $\tan \delta_{\mathrm{G}}$ of several kinds of bread dough prepared with different 2 nd fermentation time obtained at a frequency of $10^{-2} \mathrm{~Hz}$. 
パン生地の $\tan \delta_{\varepsilon}$ の值が 2 次発酵時間により異なったのは, パン生地内部の不均一構造の変化に起因すると考えられる. パン生地は, 主にタンパク質, 脂質, デンプン粒, 電解質 $(\mathrm{NaCl}$ ，遊離アミノ酸，有機酸など），非電解質（糖質など） および水からなる導電性のある誘電体かつ粘弾塑性体であ る連続相に, 絶縁体である二酸化炭素ガス気泡が分散した構 造であると考えられている. ${ }^{41)}$ 次発酵の進行に伴ってパン生 地における二酸化炭素ガス気泡の体積分率が増加するので, 単位体積当たりのパン生地の導電率は低下寸る. しかし，パ ン酵母や乳酸菌によってパン生地中に存在する遊離アミノ 酸は代謝されるが，有機酸が産生されるのでパン生地連続相 の導電率が増加する. したがって, 単位体積当たりのパン生 地に起こる電気化学的物性の変化は, 導電性のある誘電体の 交流電圧・電流現象として捉えることができる.つまり, 感 応電荷の遅延発生に由来する誘電現象および導電電荷によ る電流・放電に由来する導電現象とが同時に起きていること になる。

2次発酵時間が 50 分間までは, 二酸化炭素ガス気泡の体積 分率の増加によるパン生地の導電率の低下，ならびにパン酵 母や乳酸菌が産生する有機酸の増加によるパン生地連続相
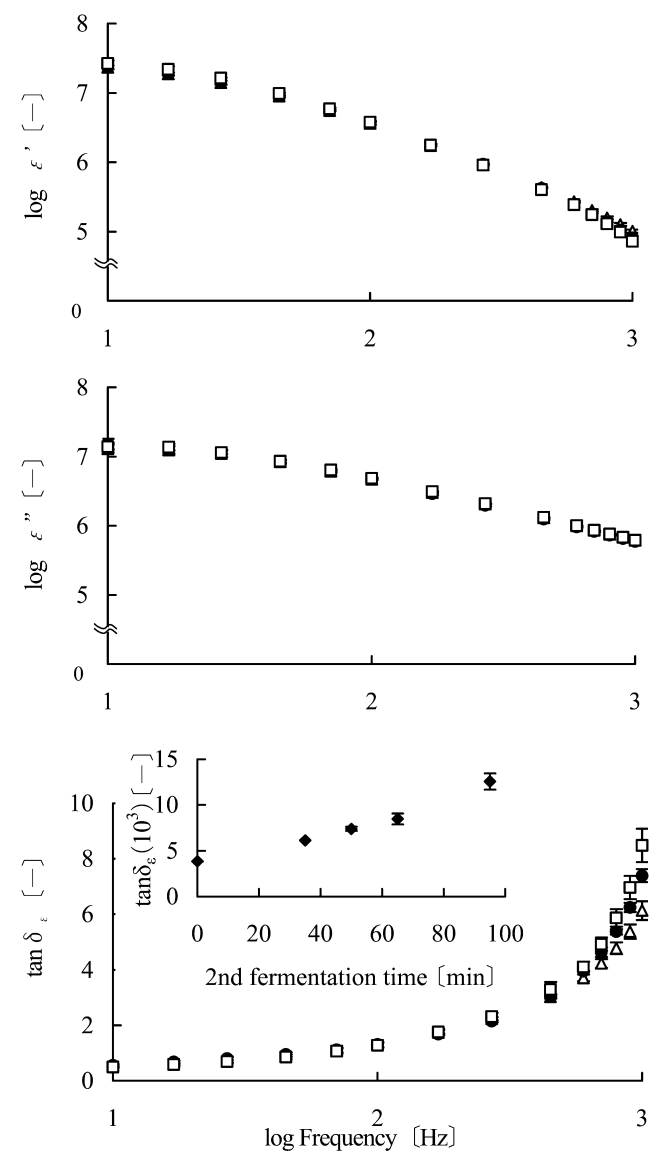

Fig. 3. Frequency dependence of permittivity $\left(\varepsilon^{\prime}\right)$, dielectric loss $\left(\varepsilon^{\prime \prime}\right)$ and dielectric loss tangent $\left(\tan \delta_{\varepsilon}\right.$ ) of several kinds of bread dough prepared with different 2 nd fermentation time.

Values are average \pm standard deviation of three replicates.

$\bullet$, fermented for $50 \mathrm{~min}$; $\triangle$, fermented for $35 \mathrm{~min}$; $\square$, fermented for $65 \mathrm{~min}$.

The inset shows $\tan \delta$ of several kinds of bread dough prepared with different 2 nd fermentation time obtained at a frequency of $10^{3} \mathrm{~Hz}$.
の導電率の増加，およびパン生地連続相の弾性と粘性の増加 (力学的損失正接 $\left(\tan \delta_{\mathrm{G}}\right)$ が小さいので粘性に比べて弾性の 寄与割合が大きい）による電荷（イオン）の移動性の低下が 同時に生じていると考えられる。したがって，単位体積当た りのパン生地では, 電気抵抗に比べて電気容量が増加する ので $\tan \delta_{\varepsilon}$ は2次発酵の経時にしたがって増加する. 一方, 2次 発酵時間が 65 分間に達すると過発酵状態になり, パン生地中 に分散している二酸化炭素ガス気泡の増加と合一（焼成した パン内相の気孔の大きさ分布から推察) によるパン生地の導 電率の低下，パン生地連続相のさらなる導電率の増加，およ びパン生地連続相の弾性と粘性がさらに増加するが粘性に 比べて弾性の寄与割合が低下することによる電荷の移動性 の低下が同時に起きていると考えられる.したがって, 2次発 酵50分間までの場合よりもパン生地の単位体積当たりの電気 抵抗に比べて電気容量が増加するので $\tan \delta$ が増加する. そ して, 2 次発酵 95 分後のパン生地でも電気抵抗に比べてさら に電気容量が増加するので $\tan \delta_{\varepsilon}$ が増加すると考えられる.

\section{2 パン生地の不凍水含量}

パン生地中の不凍水含量は2次発酵 35 分後までは減少した が，それ以降では標準偏差が大きく明確な傾向が見られな かった（Table IV）。パン生地内にはグルテン網目構造によっ て形成される狭い空隙が多く，水分子の運動は大きく束縛さ れていなくとも狭い空隙内に捕捉された水は不凍水になる 場合もある. ${ }^{42)}$ 2次発酵開始時のパン生地では, 成形工程での せん断により一部が破断されたパン生地の網目構造が接合 して架橋領域を形成し，この際に生成したミクロコンパート メント（微小な空隙）に捕捉された水が一時的に増加したと 考えられる. 2次発酵 35 分後では，発酵によって空隙が膨張 したために束縛されていた水分子の運動性が増大して自由 水としての性質が復活して凍結したと考えられる。

\section{3 パン生地のマルトース含量}

2 次発酵開始時に $9.8 \%,(\mathrm{w} / \mathrm{w})$ であったパン生地のマルトー ス含量は, 2 次発酵 35 分後または 50 分後に $9.4 \%,(\mathrm{w} / \mathrm{w})$, そし て2次発酵 95 分後には7.7\%, (w/w)にまで減少した（Table V). よって, マルトース発酵は2次発酵35 50分間で開始したと考 えられる.また，小麦粉内在の $\beta$-アミラーゼが至適 $\mathrm{pH} 5.2^{43)}$ であることから，2次発酵35分後のパン生地（ $\mathrm{pH} 5.17 ）$ と 50分後（pH 5.06）のパン生地ではマルトース発酵によりマル トースが消費されるもののマルトースが生成されるために パン生地中のマルトース含量が減少しなかったのではない かと考えられる。一方，2次発酵時間が 65 分間を超えるとパ ン生地のマルトース含量が急激に減少したのは，小麦粉内 在の $\alpha$-アミラーゼの至適 $\mathrm{pH}$ ア 5.543)であることから, $\mathrm{pH} 4.95$

Tabel IV. Unfreezable water content $[\%, w / w]$ of several kinds of bread dough prepared with different 2 nd fermentation time.

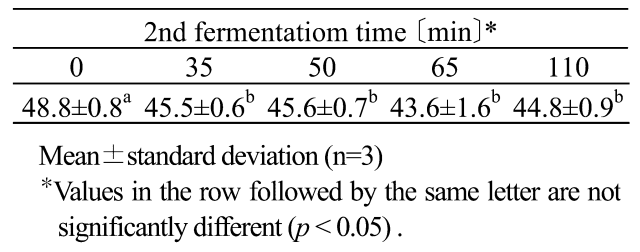


である 2 次発酵 65 分後のパン生地ではその活性が低下するた め, $\beta$-アミラーゼの基質であるデキストリンの生成が減少す

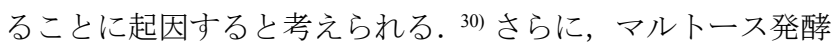

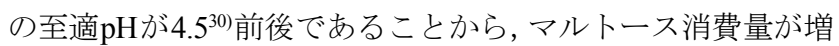
加することもパン生地中のマルトース含量が急激に減少す る要因であると考えられる。つまり, マルトース発酵は2次 発酵の中期 後期にかけての35 50分間の間で開始され, マル トース発酵が進むとともに二酸化炭素ガス発生量やパン酵 母などが産生する有機酸が増加したと考えられる. 上述した パン生地の理化学的性状を製パン工程の流れに沿ってまと めて示したのがFig. 4である.

\section{4 製パン特性}

山型食パンのローフ体積, 比容積および焼減率は2次発酵 時間が長くなるほど有意に増加し（Table VI）, 逆に内相の硬 さは有意に減少した（Table VII）。したがって，2次発酵時間を 3 水準に設定することで製パン特性に有意な差異がある山型

Table V. Maltose content $[\%, \mathrm{w} / \mathrm{w}]$ of several kinds of bread dough prepared with different 2 nd fermentation time.

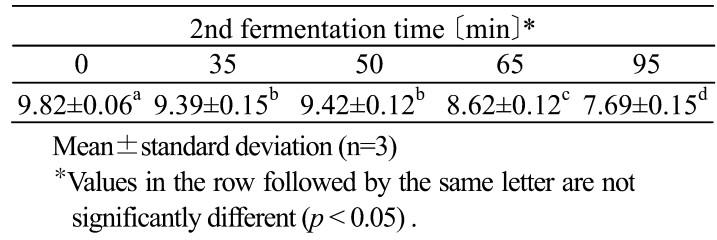

食パンを作り分けることができた. 内相の $\mathrm{T} 1$ 領域およびB3 領 域における気孔の楕円率は，2次発酵時間を65分間にして調 製した方が35分間にした場合より低くなった（Table VIII）. 2次 発酵時間を 35 分間にして調製したパンの $\mathrm{T} 1$ 領域は，気泡数， $\mathrm{X} \cdot \mathrm{Y}$ 軸フェレ径の平均值および標準偏差から気泡の大きさが 不均一で粗い気孔構造であった。一方，2次発酵時間を 65 分 間にした場合の気孔構造は，二酸化炭素ガス気泡のパン生地 への保持性が低下したためにいったんは膨張した気泡が合 一もしくは分断したために楕円率が低くなったと考えられ る。また，2次発酵時間を35分間にしたパンのB3 領域は，発 酵不足のために小さい気泡が密集した状態にあるので単位 体積中の気泡数は多い. 一方，2次発酵時間を 65 分間にした 場合には生地膨張が進行して気泡が大きくなるために単位 体積中の気泡膜の弾性が低下し，気泡の上方に存在するパン 生地からの圧力によって気泡が圧縮されて扁平になるため に，気泡数は増加するが，Y軸フェレ径は低下すると考えら れる。

\section{5 パン生地の物性と製パン特性との関連性}

製パン特性をパン生地の物性から予測することの可能性 を検討するために，パン生地の物性を独立変数，製パン特性 を従属変数として重回帰分析を行った．独立変数には，パン 生地物性のうち試料間に有意差が見られた周波数 $10^{-2} \mathrm{~Hz}$ にお ける貯蔵弾性率（以後, $G^{\prime}\left(10^{-2}\right)$ と表記する） と力学的損失 正接（以後, $\tan \delta_{\mathrm{G}}\left(10^{-2}\right)$ と表記する), 周波数 $10^{3} \mathrm{~Hz}$ におけ る誘電率 (以後, $\varepsilon^{\prime}\left(10^{3}\right)$ と表記する) と誘電損失正接（以後, $\tan \delta_{\varepsilon}\left(10^{3}\right)$ と表記する）およびパン生地比重（以後, SG と表記す
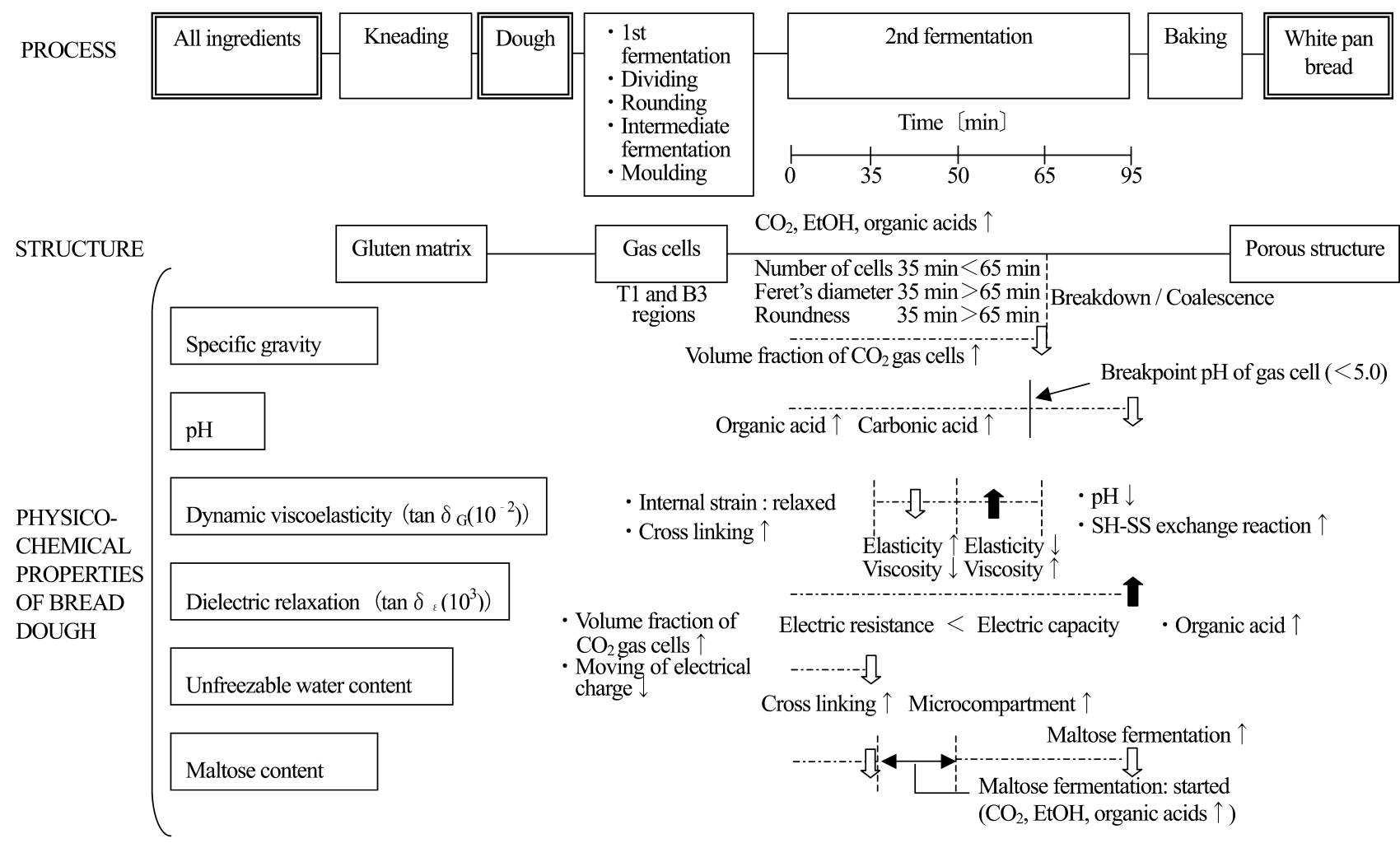

Fig. 4. Changes in physicochemical properties of bread dough during bread making.

Physicochemical properties: $\downarrow$, decrease; $\mathbf{1}$, increase.

Factor of physicochemical properties change: $\downarrow$, decrease; $\uparrow$, increase. 
る）の5変数を候補とした。 また，従属変数には製パン特性 のうち2次発酵時間により有意差が見られたローフ体積, 比 容積および内相（領域T1, M2, B3）の硬さという5変数を候 補とした.

まず，これらの独立変数と従属変数について，互いの独立 性の有無を確認するために有意水準 $5 \%(p=0.05)$ で相関分 析を行った. Table IXに示したように従属変数としての候補変 数では, すべての組み合わせで独立性がなかった。一方, 独 立变数としての候補変数の間では $G^{\prime}\left(10^{-2}\right)$ と 3 変数

Table VI. Physical properties of several kinds of white pan bread prepared with different 2 nd fermentation time.

\begin{tabular}{cccc}
$\begin{array}{c}\text { 2nd fermentation time } \\
{[\mathrm{min}]}\end{array}$ & $\begin{array}{c}\text { Loaf volume } \\
{\left[10^{-6} \mathrm{~m}^{3}\right]^{*}}\end{array}$ & $\begin{array}{c}\text { Specific volume } \\
{\left[10^{-6} \mathrm{~m}^{3} \cdot \mathrm{kg}^{-1}\right]^{*}}\end{array}$ & $\begin{array}{c}\text { Weight loss } \\
{[\%, \mathrm{w} / \mathrm{w}]^{*}}\end{array}$ \\
\hline 35 & $1160 \pm 20^{\mathrm{a}}$ & $4.29 \pm 0.07^{\mathrm{a}}$ & $13.0 \pm 0.09^{\mathrm{a}}$ \\
50 & $1330 \pm 30^{\mathrm{b}}$ & $4.98 \pm 0.13^{\mathrm{b}}$ & $13.6 \pm 0.35^{\mathrm{b}}$ \\
65 & $1440 \pm 20^{\mathrm{c}}$ & $5.42 \pm 0.09^{\mathrm{c}}$ & $14.2 \pm 0.60^{\mathrm{b}}$ \\
\hline
\end{tabular}

Mean \pm standard deviation $(\mathrm{n}=3)$

*Values in the same column followed by the same letter are not significantly different $(p<0.05)$. $\left(\varepsilon^{\prime}\left(10^{3}\right), \tan \delta_{\varepsilon}\left(10^{3}\right), \mathrm{SG}\right)$ との間の決定係数が $R^{2}=0.11 \sim 0.20$, および $\tan \delta_{\mathrm{G}}\left(10^{-2}\right)$ と 3 変数 $\left(\varepsilon^{\prime}, \tan \delta_{\varepsilon}\left(10^{3}\right), \mathrm{SG}\right)$ との間の決定 係数が $R^{2}=0.15 \sim 0.32$ というように独立性が高いことがわかっ た。よって, 従属変数にはローフ体積（以後, LVと表記す る）を選択し，独立変数を前述の六つの組み合わせにして， 重回帰分析を行うことにした.

次に, $\mathrm{LV}$ と独立変数である 5 変数 $\left(G^{\prime}\left(10^{-2}\right), \tan \delta_{\mathrm{G}}\left(10^{-2}\right)\right.$, $\left.\varepsilon^{\prime}\left(10^{3}\right), \tan \delta_{\varepsilon}\left(10^{3}\right), \mathrm{SG}\right)$ のそれぞれとの線形性を確認した結 果, $\mathrm{LV}$ と $G^{\prime}, \mathrm{LV}$ と $\tan \delta_{\mathrm{G}}\left(10^{-2}\right)$ との関係が非線形の2次関数で

Table VII. Crumb firmness $[\mathrm{kPa}]$ of several kinds of white pan bread prepared with different 2 nd fermentation time.

\begin{tabular}{cccc}
\hline Region & \multicolumn{3}{c}{ 2nd fermentation time [min] } \\
\cline { 2 - 4 } & $35^{*}$ & $50^{*}$ & $65^{*}$ \\
\hline T1 & $6.86 \pm 0.23^{\mathrm{a}}$ & $5.45 \pm 0.20^{\mathrm{b}}$ & $4.16 \pm 0.03^{\mathrm{c}}$ \\
M2 & $6.73 \pm 0.13^{\mathrm{a}}$ & $4.45 \pm 0.17^{\mathrm{b}}$ & $3.92 \pm 0.08^{\mathrm{c}}$ \\
B3 & $9.78 \pm 0.11^{\mathrm{a}}$ & $7.54 \pm 0.04^{\mathrm{b}}$ & $5.25 \pm 0.05^{\mathrm{c}}$ \\
\hline
\end{tabular}

$\mathrm{T} 1$, left end region in the upper row

$\mathrm{M} 2$, central region in the middle row

$\mathrm{B} 3$, right end region in the bottom row

Mean \pm standard deviation $(\mathrm{n}=3)$

*Values in a row followed by the same letter are not significantly different $(p<0.05)$.

Table VIII. Porous structure of crumbs in T1, M2 and B3 regions of several kinds of bread prepared with different 2nd fermentation time.

\begin{tabular}{|c|c|c|c|c|c|c|}
\hline \multirow[t]{2}{*}{ Region } & \multirow{2}{*}{$\begin{array}{c}\text { 2nd fermentation } \\
\text { time }[\mathrm{min}]\end{array}$} & \multirow{2}{*}{$\begin{array}{c}\text { Cell-total } \\
\text { area ratio }[\%]\end{array}$} & \multicolumn{2}{|c|}{ Number of Feret's diameter } & \multirow{2}{*}{$\begin{array}{c}\text { Feret's diameter } \\
\qquad \mathrm{Y}[\mathrm{mm}]^{*}\end{array}$} & \multirow{2}{*}{$\begin{array}{c}\text { Roundness } \\
{[-]^{*}}\end{array}$} \\
\hline & & & cells $[-]^{*}$ & $\mathrm{X}[\mathrm{mm}]^{*}$ & & \\
\hline \multirow{3}{*}{$\mathrm{T} 1$} & 35 & $42.8 \pm 3.7^{\mathrm{a}}$ & $114.0 \pm 1.0^{\mathrm{a}}$ & $1.65 \pm 0.19^{\mathrm{a}}$ & $1.62 \pm 0.11^{\mathrm{a}}$ & $3.21 \pm 0.11^{\mathrm{a}}$ \\
\hline & 50 & $40.8 \pm 1.8^{\mathrm{a}}$ & $125.7 \pm 0.6^{\mathrm{b}}$ & $1.46 \pm 0.02^{\mathrm{a}}$ & $1.48 \pm 0.04^{\mathrm{ab}}$ & $2.76 \pm 0.07^{\mathrm{b}}$ \\
\hline & 65 & $38.9 \pm 2.0^{\mathrm{a}}$ & $124.0 \pm 3.0^{\mathrm{b}}$ & $1.36 \pm 0.06^{\mathrm{a}}$ & $1.41 \pm 0.03^{\mathrm{b}}$ & $2.53 \pm 0.07^{\mathrm{c}}$ \\
\hline \multirow{3}{*}{ M2 } & 35 & $37.9 \pm 2.3^{\mathrm{a}}$ & $137.0 \pm 7.2^{\mathrm{a}}$ & $1.35 \pm 0.08^{\mathrm{a}}$ & $1.30 \pm 0.08^{\mathrm{a}}$ & $2.25 \pm 0.01^{\mathrm{a}}$ \\
\hline & 50 & $37.8 \pm 4.8^{\mathrm{a}}$ & $132.0 \pm 1.2^{\mathrm{a}}$ & $1.27 \pm 0.18^{\mathrm{a}}$ & $1.39 \pm 0.04^{\mathrm{a}}$ & $2.03 \pm 0.15^{\mathrm{a}}$ \\
\hline & 65 & $41.3 \pm 2.3^{\mathrm{a}}$ & $132.3 \pm 1.2^{\mathrm{a}}$ & $1.26 \pm 0.02^{\mathrm{a}}$ & $1.34 \pm 0.02^{\mathrm{a}}$ & $2.18 \pm 0.04^{\mathrm{a}}$ \\
\hline \multirow{3}{*}{ B3 } & 35 & $38.4 \pm 1.7^{\mathrm{a}}$ & $129.3 \pm 2.1^{\mathrm{a}}$ & $1.33 \pm 0.03^{\mathrm{a}}$ & $1.39 \pm 0.05^{\mathrm{a}}$ & $2.43 \pm 0.05^{\mathrm{a}}$ \\
\hline & 50 & $33.0 \pm 4.9^{\mathrm{a}}$ & $113.3 \pm 2.5^{\mathrm{b}}$ & $1.34 \pm 0.01^{\mathrm{a}}$ & $1.47 \pm 0.03^{\mathrm{a}}$ & $2.50 \pm 0.06^{\mathrm{a}}$ \\
\hline & 65 & $35.5 \pm 3.1^{\mathrm{a}}$ & $139.0 \pm 5.3^{\mathrm{c}}$ & $1.34 \pm 0.06^{\mathrm{a}}$ & $1.25 \pm 0.01^{\mathrm{c}}$ & $2.13 \pm 0.05^{\mathrm{c}}$ \\
\hline
\end{tabular}

Mean \pm standard deviation $(\mathrm{n}=3$ )

${ }^{*}$ Values in the same column at the same region followed by the same letter are not significantly different $(p<0.05)$.

Table IX. Correlation matrices among physical properties of white pan bread as candidate dependent variables (A) and bread dough as independent valuables (B).

(A)

\begin{tabular}{llllll}
\hline & LV & SV & HR-T1 & HR-M2 & HR-B3 \\
\hline LV & 1 & & & & \\
SV & $0.99^{*}$ & 1 & & & \\
HR-T1 & $-0.97^{*}$ & $-0.97^{*}$ & 1 & & \\
HR-M2 & $-0.95^{*}$ & $-0.95^{*}$ & $0.95^{*}$ & 1 & \\
HR-B3 & $-0.98^{*}$ & $-0.99^{*}$ & $0.99^{*}$ & $0.93^{*}$ & 1 \\
\hline
\end{tabular}

(B)

\begin{tabular}{llllll}
\hline & $\mathrm{G}^{\prime}\left(10^{-2}\right)$ & $\tan \delta_{\mathrm{G}}\left(10^{-2}\right)$ & $\varepsilon^{\prime}$ & $\tan \delta_{\varepsilon}\left(10^{3}\right)$ & $\mathrm{SG}$ \\
\hline $\mathrm{G}^{\prime}\left(10^{-2}\right)$ & 1 & & & & \\
$\tan \delta_{\mathrm{G}}\left(10^{-2}\right)$ & $-0.91^{*}$ & 1 & & & \\
$\varepsilon^{\prime}\left(10^{3}\right)$ & -0.45 & 0.57 & 1 & & \\
$\tan \delta_{\varepsilon}\left(10^{3}\right)$ & 0.33 & -0.39 & $-0.85^{*}$ & 1 & \\
$\mathrm{SG}$ & -0.33 & 0.44 & $0.96^{*}$ & $-0.93^{*}$ & 1 \\
\hline
\end{tabular}

LV, loaf volume; SV, specific volume; HR-T1, crumb firmness of region T1; HR-M2, crumb firmness of region M2 HR-B3, crumb firmness of region B3; $G^{\prime}\left(10^{-2}\right)$, storage modulus at $10^{-2} \mathrm{~Hz} ; \tan \delta_{\mathrm{G}}\left(10^{-2}\right)$, mechanical loss tangent $\varepsilon^{\prime}\left(10^{3}\right)$, dielectric loss; tan $\delta_{\varepsilon}\left(10^{3}\right)$, dielectric loss tangent; SG, specific gravity; significant at $p<0.05$ 
あった（Fig. 5).そこで，今回は非線形重回帰分析を用いて モデル式を推定することにした. ${ }^{44)} 95 \%$ の信頼区間で平方和 の収束基準を $1.0 \times 10^{-8}$, パラメータの収束基準を $1.0 \times 10^{-8}$ とし たLevenberg-Marquardt法45)で推定したところ，LVを精度よく 予測するモデル式は次式(4) (9)のとおりであった.
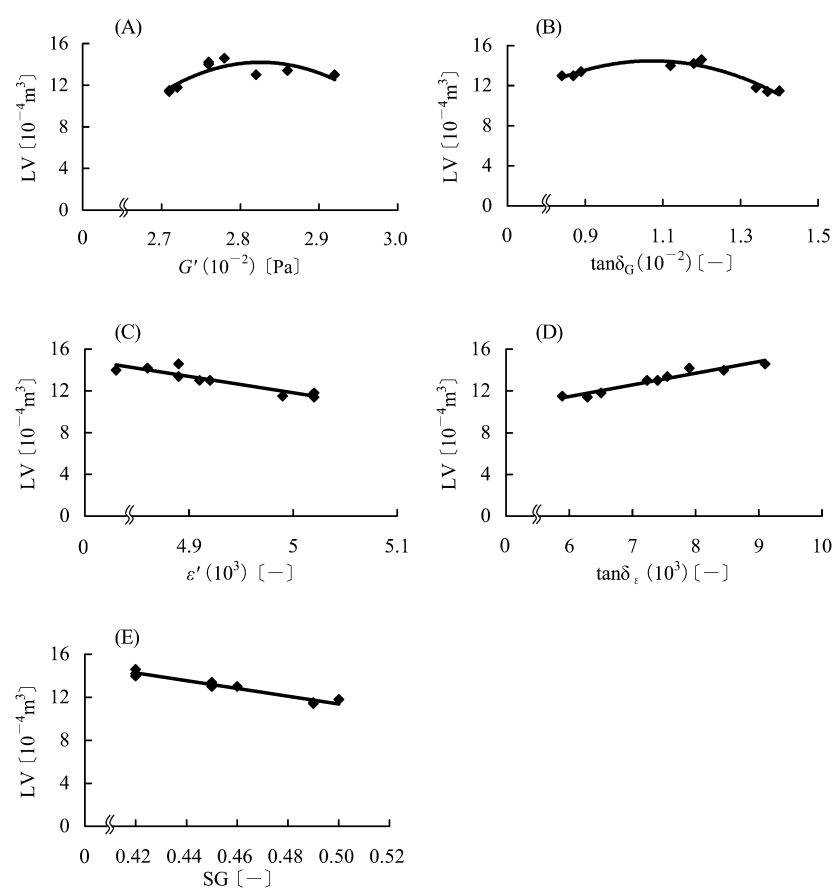

Fig. 5. Relationships between LV and physical properties of several kind of bread dough.

Abbreviations are the same in Table IX.

The symbols $(\checkmark)$ represent the experimental data and the solid lines are the regression lines.

$$
\begin{aligned}
\mathrm{LV}= & -6.6+0.7 \tan \delta_{\varepsilon}\left(10^{3}\right) \\
& +28.5 \tan \delta_{\mathrm{G}}\left(10^{-2}\right)-13.5 \tan \delta_{\mathrm{G}}\left(10^{-2}\right)^{2} \\
\left(R^{2}=\right. & 0.94) \\
\mathrm{LV}= & -178.6-33.41 \mathrm{SG} \\
& +145.0 G^{\prime}\left(10^{-2}\right)-25.39 G^{\prime}\left(10^{-2}\right)^{2} \\
\left(R^{2}=\right. & 0.93) \\
\mathrm{LV}= & -262.3+1.0 \tan \delta{ }_{\varepsilon}\left(10^{3}\right) \\
& +188.4 G^{\prime}\left(10^{-2}\right)-33.07 G^{\prime}\left(10^{-2}\right)^{2} \\
\left(R^{2}=\right. & 0.92) \\
\mathrm{LV}= & 9.7-23.7 \mathrm{SG}^{2}+27.6 \tan \delta{ }_{\mathrm{G}}\left(10^{-2}\right) \\
& -13.0 \tan \delta_{\mathrm{G}}\left(10^{-2}\right)^{2} \\
\left(R^{2}=\right. & 0.92) \\
\mathrm{LV}= & 24.2-7.1 \varepsilon^{\prime}\left(10^{3}\right) \\
& +45.7 \tan \delta_{\mathrm{G}}\left(10^{-2}\right)-21.2 \tan \delta{ }_{\mathrm{G}}\left(10^{-2}\right)^{2} \\
\left(R^{2}=\right. & 0.91)
\end{aligned}
$$

$$
\begin{aligned}
\mathrm{LV}= & -395.7-13.5 \varepsilon^{\prime}\left(10^{3}\right) \\
& +337.2 G^{\prime}\left(10^{-2}\right)-59.8 G^{\prime}\left(10^{-2}\right)^{2} \\
\left(R^{2}=\right. & 0.87)
\end{aligned}
$$

ここで, LVの単位は $\left[10^{-4} \mathrm{~m}^{3}\right]$ である.

以上のことから，製パン条件のうちパンの品質に大きな影 響を与えることが知られている2次発酵時間を意図的に5水準 に変化させて調製したパン生地，およびそれから調製したパ ンについては，パン生地の物性值を独立変数にした非線形重 回帰モデル式により製パン特性（パンのローフ体積）を予測 することが可能であると考えられる. 今後は，パンの品質に 大きく影響を及ぼすもう一つの因子であるパン生地の混捏 条件についても同様に検討寸る予定である.

\section{4. 結 論}

パンの品質に大きな影響を及ぼすことが知られている2次 発酵時間を 5 水準 (0分間, 35 分間, 50分間, 65分間, 95分間) に変化させてパン生地を調製し, このパン生地物性（比重, $\mathrm{pH}$, 粘弾性, 誘電率)，不凍水含量，マルトース含量，およ びこれらのパン生地から調製した山型食パンの製パン特性 (ローフ体積, 比容積, 焼減率, 内相の硬さ, 内相の気孔構 造）を測定した。そして，パン生地物性と製パン特性との関 連性を検討し，次の結果を得た。

（1） 2次発酵時間を5水準に変えることにより物性に有意差の あるパン生地, および 2 次発酵時間を 3 水準に変えること により製パン特性に有意差がある山型食パンを作り分け ることができた。

(2) 2 次発酵時間が長くなるほどパン生地の比重と $\mathrm{pH}$ は低下 し, 周波数 $10^{3} \mathrm{~Hz}$ での誘電損失正接 $\tan \delta_{\varepsilon}\left(10^{3}\right)$ は増加した. 周波数 $10^{-2} \mathrm{~Hz}$ での力学的損失正接 $\tan \delta_{\mathrm{G}}\left(10^{-2}\right)$ は2 次発酵時 間50分間で極小值をとった。また，2次発酵後期に盛んに なるマルトース発酵によって 2 次発酵 65 分後以降にパン 生地のマルトース含量が急激に減少した. 2次発酵の進行 に伴うパン生地の物性変化は, 粘弾塑性体と見なせるパ ン生地の連続相に気泡が分散した構造に及ぼすパン酵母 が産生する二酸化炭素ガス気泡ならびにパン酵母と乳酸 菌などが産生する有機酸の影響, 誘電性のある誘電体と 見なせるパン生地で同時に起きている誘電現象および導 電現象から説明することができた.

（3） 2次発酵時間が長くなるほど山型食パンのローフ体積は増 加し, 内相は柔らかくなり, 気泡の楕円率は低下した.

（4）パン生地の周波数 $10^{-2} \mathrm{~Hz}$ での貯蔵弾性率や力学的損失正 接, ならびに $10^{3} \mathrm{~Hz}$ での誘電率や誘電損失正接を独立変数 にして製パン特性の一つであるローフ体積を精度よく予 測する非線形回帰式を得ることができた $\left(R^{2}=0.87 \sim 0.94\right)$.

\section{謝 辞}

本研究を遂行するにあたり, 強力小麦粉の入手に便宜をは かって頂いた株小松製菓に感謝いたします。 


\section{REFERENCES}

1) The Ministry of Agriculture, Forestry and Fisheries of Japan, Cereals and the supply and demand of tea The trend and a prospect, http:// www. kanbou. maff. go. jp/ www/ jk/ koku/ 15koku/ 15koku. htm\#komugi

2) Watanabe A, Yokomizo K, Eliasson AC, Cereal Chem, 80, 281 (2003).

3) O'Brien M, Mueller A, Scannell N, Arendt E, J Food Eng, 56, 256 (2003).

4) Cuq B, Yildiz E, Kokini J, Cereal Chem, 79, 129 (2002).

5) Edwards NM, Mulvaney SJ, Scanlon MG, Dexter JE, Cereal Chem, 80, 755 (2003).

6) Singh N, Bajaj IK, Sihgh RDH, Gujral HS, J Food Eng, 56, 89 (2003).

7) Butow BJ, Gras PW, Haraszi R, Bekes F, Cereal Chem, 79, 826 (2002).

8) Sharadanant R, Khan K, Cereal Chem, 80, 764 (2003).

9) Bauer N, Koehler P, Wieser H, Schieberle P, Cereal Chem, 80, 787 (2003).

10) Szczesniak AS, Cereal Foods World, 33, 841 (1988).

11) Ribotta PD, Pérez GT, León AE Añón MC, Food Hydrocolloids, 18, 305 (2004).

12) Schober TJ, Clark CI, Kuhn M, Cereal Chem, 79, 408 (2002).

13) Toufeili I, Lambert IA, Kokini JL, Cereal Chem, 79, 138 (2002).

14) Campbell GM, Sanchez RH, Rodriguez RP, Merchan ML, Cereal Chem, 78, 272 (2001).

15) Collado M, Deleyn ID, Cereal Food World, 45, 214 (2000).

16) Ito M, Yoshikawa S, Asami K, Hanai T, Cereal Chem, 69, 325 (1992).

17) Laaksonen TJ, Roos YH, Cereal Sci, 37, 319 (2003).

18) Hanekura Y, Nippon Shokuhin Kagaku Kogaku Kaishi, 51, 109 (2004).

19) Yoshida C, Yano M, Danno G, Food Sci Technol Int Tokyo, 2 , 209 (1996).

20) Sapirstein HD, Suchy J, Cereal Chem, 76, 164 (1999).

21) Chung OK, Ohm JB, Caley MS, Seabourm BW, Cereal Chem, 78, 493 (2001).

22) Dobraszczyk BJ, Schofield JD, Cereal Chem, 79, 607 (2002).

23) Chatterjee S, Price B (Sawa T, Kano S), "Kaikibunseki no Jissai”, p224, (1981), Shin-yo-sha, Tokyo.

24) Harashima A, “Kyoyobuturigaku”, p60, (1992), Gakujutsu Tosho, Tokyo.
25) Clarke CI, Schober TJ, Arendt EK, Cereal Chem, 79, 640 (2002).

26) Tronsmo KM, Magnus EM, Baardseth $P$, Schofield $D$, Aamodt A, Færgestad EM, Cereal Chem, 80, 587 (2003).

27) Navickls L, Anderson R, Bagley E, Jasber B, J Texture Studies, 13, 249 (1982).

28) American Association of Cereal Chemists, "Approved Methods of the AACC", 9th ed Method 44-15A, (1995), The Association: St. Paul, MN.

29) Tanaka Y, Matumoto H, "Seipan no Kagaku I Seipan Process no Kagaku”, p118, (1991), Korin, Tokyo.

30) Hukui S, "Kangento no Teiryoka”, p45, (1985), Japan Scientific Societies Press, Tokyo.

31) American Association of Cereal Chemists, "Approved Methods of the AACC”, 9th ed Method 72-10, (1995), The Association: St. Paul, MN.

32) Nippon Pankenkyujo, "Shikenho”, p3, (1986), Nippon Pankenkyujo, Tokyo.

33) American Association of Cereal Chemists, "Approved Methods of the AACC", 9th ed Method 74-09, (1995), The Association: St. Paul, MN.

34) Miura M, Elizabeth Arnold Fuji Foundation 1996 Annual Report, p27, (1997).

35) Nagata Y, Yoshida M, “Tokeiteki Tahenryo no Kiso”, p79, (1997), Scientist, Tokyo.

36) Tanaka Y, Matumoto H, "Seipan no Kagaku I Seipan Process no Kagaku”, p106, (1991), Korin, Tokyo.

37) Ferry D, "Viscoelastic Properties of Polymers", 3rd ed, (1980), John Wiley and Sons Inc, NY, p24.

38) Murakami K, “Rheology Kisoron”, p144, (1991), Sangyo Tosho, Tokyo.

39) Tanaka Y, Matumoto H, "Seipan no Kagaku I Seipan Process no Kagaku”, p86, (1991), Korin, Tokyo.

40) Yamauchi H, "Shokuhin Tanpakushitu no Kagaku”, p92, (1984), Shokuhin Shizai Kenkyukai, Tokyo.

41) Hanai T, “Hukinshitsukozo to Yudenritsu”, p174, (2000), Yoshioka Shoten, Kyoto.

42) Murase N, Goda K, Trans of the JAR, 3, 1 (1986).

43) Onishi M, Sakano Y, “Amylase”, p70, p142, (1987), Japan Scientific Societies Press, Tokyo.

44) Ishimura S, "SPSS niyoru Tahenryo Data Kaiseki no Tejun", p54, (2000), Tokyo Tosho, Tokyo.

45) Iri M, Konno T, Tone K, “Saitekika Handbook”, p58, (1996), Asakura Shoten, Tokyo. 